\title{
Phenotypic and Genetic Analysis of Epiphytic Pseudomonas syringae Populations from Sweet Cherry in Michigan
}

\author{
Lisa J. Renick, Andrea G. Cogal, and George W. Sundin, Department of Plant Pathology, Michigan State Univer- \\ sity, East Lansing 48824
}

\begin{abstract}
Renick, L. J., Cogal, A. G., and Sundin, G. W. 2008. Phenotypic and genetic analysis of epiphytic Pseudomonas syringae populations from sweet cherry in Michigan. Plant Dis. 92:372378.

A severe outbreak of bacterial canker occurred on sweet cherry in Michigan in 2002. Blossom infection and subsequent canker formation was observed following a prolonged freeze event during bloom. Epiphytic blossom isolates of Pseudomonas syringae were recovered from 39 orchards from the three major cherry-growing areas (southwest [SW], west-central [WC], and northwest $[\mathrm{NW}]$ ) of Michigan in 2003 and 2004. Average $P$. syringae populations over 2 years were 4.0, 5.1, and $4.8 \log _{10} \mathrm{CFU} / \mathrm{g}$ of blossom tissue from the SW, WC, and NW areas, respectively. In 2003 , copper-resistant $P$. syringae comprised $47.4,21.1$, and $3.1 \%$ of the total populations from the SW, WC, and NW areas, respectively, and levels of copper resistance were similar in 2004. Identification of 10 randomly chosen isolates from each orchard using polymerase chain reaction (PCR) assays indicated that 75 and 52\% of the isolates from 2003 and 2004, respectively were P. syringae pv. syringae and that $1 \%$ and $23 \%$ of the isolates from 2003 and 2004, respectively, were $P$. syringae pv. morsprunorum. In addition, we were unable to determine the pathovar status of approximately $25 \%$ of the isolates each year, suggesting that a third $P$. syringae pathovar also was present in Michigan sweet cherry orchards. Pathogenicity on immature cherry fruit was confirmed for all $P$. syringae isolates. The frequency of ice nucleation was assessed for 44 individual $P$. syringae pv. syringae isolates, and the mean number of cells per active ice nucleus was 1,883 . Extrapolating from this result, we estimated that active ice nuclei are present on most sweet cherry blossoms in Michigan orchards. Genetic fingerprinting of $P$. syringae pv. syringae using arbitrarily primed PCR indicated a high level of diversity and a clear differentiation of these organisms from the $P$. syringae isolates of unknown pathovar. A 2year field trial evaluating the effect of dormant copper applications in spring and reduced-rate copper applications prior to bloom showed that these treatments were inconsistent in reducing $P$. syringae populations on blossoms.
\end{abstract}

Bacterial canker, caused by Pseudomonas syringae pvs. syringae and morsprunorum, is an important disease of sweet cherry (Prunus avium L.), tart cherry ( $P$. cerasus L.), apricot (P. armeniaca L.), and other stone fruit, with symptoms that include blossom blast and spur dieback, leaf and fruit lesions, cankers with associated gummosis of woody tissue, loss of scaffold limbs, and overall decreased fruit yields (14). Young sweet cherry trees infected with bacterial canker are at high risk of being killed by this disease due to the endophytic nature of the infection and systemic movement of the pathogen in woody tissue. Endophytic Pseudomonas syringae pv. syringae populations can be established in a number of ways. One method is through leaf scar infection in autumn, which can lead directly to canker

Corresponding author: G. W. Sundin

E-mail: sundin@msu.edu

Accepted for publication 1 October 2007.

doi:10.1094/PDIS-92-3-0372

(C) 2008 The American Phytopathological Society formation or to internal migration and colonization of dormant buds $(5,42)$. Colonized buds can remain symptomless overwinter or can be killed by the pathogen, leading to the dead bud symptom which typically is associated with canker formation. Systemic invasion of shoots following leaf or blossom infection also can occur (8). Epiphytic P. syringae pv. syringae populations provide inoculum at critical phases of the disease cycle. Leaf surface populations, which typically are reduced during summer months, increase in autumn and enable pathogen colonization of leaf scars $(5,42)$. Populations that overwinter in dormant buds then provide the primary inoculum for epiphytic blossom colonization the following spring.

Management of bacterial canker has been exceedingly difficult and is impacted by the lack of effective bactericides and partially endophytic nature of the pathogen. The only bactericide registered for bacterial canker management is copper, which is of limited use because sweet cherry trees are susceptible to copper phytotoxicity following bud break in spring. Copper sprays traditionally have been applied during leaf drop in autumn to re- duce leaf scar infection and as dormant sprays prior to bud break to reduce pathogen populations either on the surface of cankers or emerging from dormant buds. Copper has been effective in reducing bacterial canker symptoms in some studies $(30,47)$ but not in others $(9,31)$, and the effect of copper on reducing blossom populations of $P$. syringae has not been reported. The efficacy of copper also has been limited by the development of copper-resistant $\left(\mathrm{Cu}^{\mathrm{R}}\right)$ strains of $P$. syringae pv. syringae (41). Cultural control strategies targeting bacterial canker also have been attempted. For example, fertilization with time-released nitrogen, phosphorus, and potassium plus micronutrients, in combination with dormant copper sprays, resulted in a greater reduction in the severity of bacterial canker in French prune than copper sprays alone (31). The importance of fertilization in bacterial canker control (6) presumably is due to enhancing soil nutritional status, because poor soil nutrition is an important predisposition factor for this disease (27).

The occurrence of frost injury or exposure to freezing temperatures is another important predisposition factor in canker development by $P$. syringae pv. syringae on various woody hosts $(16,35,45)$. Most strains of $P$. syringae pv. syringae are ice nucleation active (INA), and can serve as ice nuclei that can catalyze ice formation at relatively warm temperatures. Ice nucleation plays an important role in frost injury on a number of agricultural crops (20). In Michigan, sweet cherry orchards are at risk for frost injury almost every year; however, damage usually is sporadic and typically results in the killing of only small numbers of flowers without further $P$. syringae infection into shoots. On 22 May 2002, a hard radiational frost occurred in northwest and west-central Michigan, with sustained temperatures of $-3.3^{\circ} \mathrm{C}$ over an 11 -h duration. This freeze event resulted in extensive blast symptoms of sweet cherry blossoms and was followed by widespread shoot infection, canker formation, and death of trees (14). This significant infection event led us to reassess the epidemiology of bacterial canker in Michigan through analysis of the blossom phase of this disease. We sought to test the hypothesis that INA $P$. syringae pv. syringae exist as epiphytes on sweet cherry blossoms and that such bacteria likely contributed to the severe bacterial canker 
epidemic following the prolonged 2002 spring bloom freeze event in Michigan. Our second hypothesis was that populations of INA $P$. syringae pv. syringae epiphytes are high in Michigan sweet cherry orchards because copper bactericide spray timings based on current practices are ineffective in reducing populations or copper resistance contributes to the reduced efficacy of copper bactericides. Our objectives were to (i) survey the epiphytic $P$. syringae pvs. syringae and morsprunorum populations on sweet cherry blossoms in Michigan orchards; (ii) examine phenotypic characters of these isolates, including pathogenicity, copper resistance, and ice nucleation frequency; and (iii) examine the genetic similarity of isolates. Our fourth objective was to evaluate the role of dormant and prebloom copper applications in the reduction of epiphytic $P$. syringae populations on sweet cherry blossoms.

\section{MATERIALS AND METHODS}

Orchard surveys and bacterial isolation. Samples of symptomless blossoms were collected from 39 sweet cherry orchards in eight counties along the western coast of Michigan in 2003 and 2004. These orchard locations were representative of the largest sweet-cherry-growing regions in the state. Five samples were taken per orchard location, each consisting of five randomly chosen blossom clusters (one cluster per tree). Blossom samples were placed in plastic bags and transported to the laboratory on ice. The samples were weighed and blossoms were placed in sterile flasks containing $25 \mathrm{ml}$ of $0.5 \times$ phosphate buffered saline (PBS), which then were shaken vigorously by hand for 2 min. The resulting PBS suspensions were serially diluted in 10-fold steps and appropriate dilutions were plated in triplicate on mannitol glutamate (MG) medium (13) and MG amended with copper sulfate (MGcu) at $250 \mu \mathrm{g} / \mathrm{ml}$. Single colonies of $P$. syringae growing on $\mathrm{MGcu}$ previously were shown to be copper resistant due to the carriage of plasmid-encoded copperresistance genes (38). Fluorescent colonies on MG and on MGcu with a morphology typical of $P$. syringae were identified visually and enumerated after $48 \mathrm{~h}$ of incubation at $28^{\circ} \mathrm{C}$ and the proportion of copperresistant isolates determined. Bacterial isolates subsequently were cultured routinely on MG medium or in King's B (15) liquid medium at $28^{\circ} \mathrm{C}$, unless otherwise noted.

Identification of $\boldsymbol{P}$. syringae pathovar. Up to 10 presumed $P$. syringae isolates were selected randomly from each orchard site in 2003 and 2004 for analysis. Although samples were plated onto both MG and MGcu media, isolates chosen for further study were selected from the MG plates. Each isolate was single colony purified and stored in $15 \%$ glycerol at $-70^{\circ} \mathrm{C}$. For pathovar identification, we utilized PCR with previously characterized diagnostic primers for $P$. syringae pvs. syringae and morsprunorum that was preceded by a phenotypic test for esculin hydrolysis (34). The ability to hydrolyze esculin distinguishes $P$. syringae pv. syringae from $P$. syringae pv. morsprunorum (12). In our analyses, esculin-hydrolyzing bacteria first were characterized by PCR using a primer set (5'-CAGCGGCGT TGCGTCCATTGC-3' and 5'-TGCCGC CGACGATGTAGACCAGC-3') designed to amplify a 1,040 -bp region of the syringomycin biosynthetic gene syrD (3). Amplification reactions were conducted using an MJ Research MiniCycler for 35 cycles as follows: $95^{\circ} \mathrm{C}$ for $2 \mathrm{~min}, 94^{\circ} \mathrm{C}$ for 1 min, annealing at $60^{\circ} \mathrm{C}$ for $1 \mathrm{~min}$, and $72^{\circ} \mathrm{C}$ for $90 \mathrm{~s}$.

Bacteria that were incapable of hydrolyzing esculin first were characterized by PCR using a primer set (5'-GGCGCT CCCTCGCACTT-3' and 5'-GGTATTGGC GGGGGTGC-3') designed to amplify a 650-bp region of the $c f l$ gene in the coronatine gene cluster (2). Amplification was conducted as previously described, with an annealing temperature of $67^{\circ} \mathrm{C}$ as the only exception. Isolates for which one primer set failed to amplify also were examined with the other set. We also randomly chose 10 isolates identified as $P$. syringae pvs. syringae or morsprunorum and confirmed that the respective other set of identification primers did not yield a product.

Phenotypic analyses. Pathogenicity tests were conducted on all of the isolates recovered using immature green cherry fruit, as previously described (12), with a few modifications. Stab-wounded immature green cherry fruit were inoculated with $1 \mu \mathrm{l}\left(10^{5} \mathrm{CFU} / \mu \mathrm{l}\right)$ of each strain in duplicate to detect pathogenic isolates. Bacteria first were grown overnight in liquid $\mathrm{MG}$ cultures shaken at $28^{\circ} \mathrm{C}$. Immature inoculated green cherry fruit were stored inverted, with freshly cut stems submerged in water to maintain turgor pressure in the fruit. Observations were made after $48 \mathrm{~h}$, and bacteria that caused dark necrotic lesions were considered pathogenic. Water control and known pathogenic $P$. syringae pv. syringae and $P$. syringae pv. morsprunorum strains were included in each test group.

Ice nucleation activity of the pathogenic $P$. syringae pv. syringae isolates was assessed by the droplet-freezing method (44). A Brinkmann Lauda refrigerated bath containing a 50:50 mixture of ethylene glycol:water was maintained at $-5^{\circ} \mathrm{C}$ for the assays. Droplets were pipetted onto an aluminum "boat" coated with paraffin wax and floated in the bath. Ice nucleation activity was assessed after $15 \mathrm{~min}$ by the presence of frozen droplets. The frequency of INA cells was determined for a subset of $P$. syringae pv. syringae isolates (randomly chosen, one per orchard) using a previously described quantitative droplet- freezing method (22). Briefly, $40 \quad 10-\mu l$ droplets of a cell suspension were pipetted onto aluminum foil boats and floated in a $-5^{\circ} \mathrm{C}$ bath. After $15 \mathrm{~min}$, the number of frozen drops was recorded. If all 40 drops were frozen, the cell suspension was diluted and the droplet-freezing method was repeated until the number of frozen droplets was between 1 and 40 . Once the number of frozen droplets was between 1 and 40 , the cell suspensions were serially diluted in 10-fold steps and plated as described above to determine cell concentrations.

The ice nucleation frequency of each bacterium tested was expressed as the cumulative ice nuclei concentration, $\eta$, at a given temperature $\left(-5^{\circ} \mathrm{C}\right)$, with $\eta$ determined using the equation $\eta=1 / V[\ln (1 / 1-$ $f)] 1 / X$, where $\eta=$ the cumulative concentration of active ice nuclei at the freezing temperature, $f=$ the fraction of drops frozen, $V=$ the volume of an individual droplet, and $X=$ the cell concentration in a droplet of volume $V(44)$.

Minimal inhibitory concentration of copper determination and conjugation experiments. All isolates were streaked onto MGcu to assess copper resistance. We previously determined that $P$. syringae bacteria able to grow on MGcu medium are resistant to copper and contain plasmid-encoded copper-resistance genes (38). A subset of 56 isolates, including $49 P$. syringae pv. syringae and seven $P$. syringae, was chosen randomly for copper minimal inhibitory concentration (MIC) analysis. Copper-resistant isolates were streaked in duplicate on copper-amended MG plates with copper concentrations ranging from 0.8 to $3.2 \mathrm{mM}$ to determine the MIC for each isolate (4). If the organism grew at a similar rate on copperamended and non-copper-containing media, the concentration of copper was considered to be noninhibitory.

DNA fingerprinting. DNA fingerprinting was used to assess the relative genetic similarity of the $P$. syringae pv. syringae population in Michigan sweet cherry orchards. We used known pv. syringae strains and unknown pathovar $P$. syringae isolates as outgroup strains in the analysis. PCR amplifications were done using BOX or enterobacterial repetitive intergenic consensus (ERIC) primers (25) in 25- $\mu \mathrm{l}$ reactions containing $4 \mu \mathrm{g}$ of bovine serum albumin, $1.25 \mathrm{mM}$ deoxynucleoside triphosphates, $10 \%$ dimethyl sulfoxide, and $1.5 \mathrm{U}$ of $\mathrm{Taq}$ polymerase in a previously described salt buffer (17). Whole bacterial cells, placed in the tubes using a sterile toothpick, served as the source of template DNA. Amplification reactions were performed using an MJ Research MiniCycler as follows: 1 cycle at $95^{\circ} \mathrm{C}$ for 6 min; 5 cycles consisting of $94^{\circ} \mathrm{C}$ for 1 $\min , 40^{\circ} \mathrm{C}$ for $1 \mathrm{~min}$, and $65^{\circ} \mathrm{C}$ for $8 \mathrm{~min}$; 30 cycles consisting of $94^{\circ} \mathrm{C}$ for $1 \mathrm{~min}$, $50^{\circ} \mathrm{C}$ for $1 \mathrm{~min}$, and $65^{\circ} \mathrm{C}$ for $8 \mathrm{~min}$; 
1 cycle at $65^{\circ} \mathrm{C}$ for $16 \mathrm{~min}$; and a final soaking step at $4^{\circ} \mathrm{C}$ (40). DNA fingerprints were generated at least two times for each isolate.

PCR amplicons were separated on $1.5 \%$ agarose gels and compared visually. Comparisons of amplicon patterns always were done for preparations run in adjacent lanes of the same gel. A matrix of total DNA fragments present in the sample was generated with individual isolates given a value of 1 or 0 for the presence or absence of a particular sized fragment, respectively. Cluster analysis of these data was performed using the Jaccard similarity coefficient, and a dendrogram was generated using NTSYS-pc (Applied Biostatistics Inc., Setauket, NY).

Copper-efficacy field spray trials. The role of dormant copper applications in spring and reduced-rate copper applica- tions prior to bloom in the reduction of $P$. syringae populations on sweet cherry blossoms was evaluated in a field trial. Experiments were conducted in 2003 and 2004 in a block of 18-year-old sweet cherry (Prunus avium cv. Vega) trees located at the Northwest Michigan Horticultural Research Station, near Traverse City, MI. The background level of copper resistance among Pseudomonas syringae isolates from this orchard was determined by screening isolates from 22 blossom and leaf samples taken over a 3-month period in 2002. A randomized complete block design was utilized with four single-tree replicates per treatment. Two copper compounds were tested, Cuprofix 20 Disperss (Cerexagri, King of Prussia, PA) at a rate of $11.2 \mathrm{~kg} / \mathrm{ha}$ (metallic equivalent $=2.2$ $\mathrm{kg} / \mathrm{ha}$ ) and Kocide DF (Dupont, Newark, $\mathrm{DE}$ ) at a rate of $7.8 \mathrm{~kg} / \mathrm{ha}$ (metallic equiva-

Table 1. Pseudomonas syringae populations and percentage of copper-resistant isolates from symptomless sweet cherry blossoms from Michigan orchards

\begin{tabular}{|c|c|c|c|c|}
\hline \multirow[b]{3}{*}{ Orchard } & \multicolumn{4}{|c|}{ P. syringae blossom populations ${ }^{\mathrm{a}}$} \\
\hline & \multicolumn{2}{|c|}{2003 Samples } & \multicolumn{2}{|c|}{2004 Samples } \\
\hline & Log CFU/g & $\mathrm{Cu}^{\mathrm{R}}(\%)$ & $\log$ CFU/g & $\mathrm{Cu}^{\mathrm{R}}(\%)$ \\
\hline \multicolumn{5}{|c|}{ Southwest } \\
\hline 1 & 4.1 & 89.5 & 4.0 & 0.2 \\
\hline 2 & 2.9 & 28.7 & 4.7 & 0.4 \\
\hline 3 & 5.0 & 5.9 & 3.6 & 74.8 \\
\hline 4 & 5.8 & 6.9 & 5.2 & 52.6 \\
\hline 5 & 3.3 & 57.6 & 5.5 & 19.1 \\
\hline 6 & 3.1 & 55.3 & 3.2 & 66.2 \\
\hline 7 & 2.7 & 88.2 & 2.8 & 56.1 \\
\hline \multicolumn{5}{|c|}{ West-central } \\
\hline 8 & 6.6 & 5.8 & 5.5 & 0.2 \\
\hline 9 & 3.9 & 1.3 & 2.7 & 3.9 \\
\hline 10 & 4.5 & 38.4 & 6.3 & 39.1 \\
\hline 11 & 5.0 & 28.4 & 5.2 & 39.3 \\
\hline 12 & 5.7 & 10.6 & 5.5 & 68.3 \\
\hline \multicolumn{5}{|l|}{ Northwest } \\
\hline 13 & 4.7 & 0.8 & 6.3 & 4.9 \\
\hline 14 & 5.7 & 0.3 & 5.5 & 0.1 \\
\hline 15 & 5.8 & 0.5 & 5.1 & 31.4 \\
\hline 16 & 4.5 & 0.6 & 5.9 & 3.3 \\
\hline 17 & 4.8 & 0.2 & 5.6 & 39.7 \\
\hline 18 & 5.6 & 6.5 & 5.9 & 2.6 \\
\hline 19 & 5.1 & 4.0 & 4.7 & 0.1 \\
\hline 20 & 5.0 & 0.5 & 6.1 & 0.3 \\
\hline 21 & 4.6 & 1.6 & 5.1 & 0.1 \\
\hline 22 & 4.8 & 4.4 & 5.8 & 1.0 \\
\hline 23 & 5.0 & 5.1 & 1.9 & 16.7 \\
\hline 24 & 4.4 & 0.1 & 5.8 & 0.0 \\
\hline 25 & 6.2 & 0.0 & 6.0 & 1.2 \\
\hline 26 & 3.9 & 0.4 & 3.9 & 54.7 \\
\hline 27 & 6.0 & 0.1 & 3.2 & 3.0 \\
\hline 28 & 5.2 & 2.4 & 5.9 & 2.4 \\
\hline 29 & 4.7 & 0.0 & 6.8 & 5.5 \\
\hline 30 & 5.0 & 0.0 & 5.8 & 0.5 \\
\hline 31 & 5.0 & 7.4 & 3.6 & 50.6 \\
\hline 32 & 3.4 & 25.3 & 3.1 & 0.0 \\
\hline 33 & 5.4 & 0.0 & 2.0 & 0.0 \\
\hline 34 & 5.0 & 0.1 & 3.3 & 1.2 \\
\hline 35 & 5.2 & 2.3 & 3.2 & 44.2 \\
\hline 36 & 5.3 & 5.5 & 4.3 & 0.0 \\
\hline 37 & 5.4 & 0.1 & 2.4 & 0.0 \\
\hline 38 & 5.5 & 21.6 & 5.4 & 0.0 \\
\hline 39 & 5.4 & 0.9 & 2.5 & 0.0 \\
\hline
\end{tabular}

${ }^{\mathrm{a}} \mathrm{Log} \mathrm{CFU} / \mathrm{g}=\log _{10}$ number of plate recovered colonies divided by the sample mass and $\mathrm{Cu}^{\mathrm{R}}(\%)=$ the number of plate-recovered colonies on mannitol glutamate (MG) amended with $250 \mu \mathrm{g}$ copper sulfate divided by the number of recovered colonies on MG. lent $=3.1 \mathrm{~kg} / \mathrm{ha})$. Treatments consisted of either two dormant applications alone or of two dormant applications plus one application at $25 \%$ of the dormant rate applied at the "popcorn" stage (white petals visible but blossoms unopened). Sprays were applied with a custom-built research plot sprayer fit with a JBS model 705 hand gun (John Bean Sprayer Co., Conway, AR) at 300 to $350 \mathrm{psi}\left(21.1 \mathrm{~kg} / \mathrm{cm}^{2}\right)$ and 2,801 liters of water per hectare. An unsprayed control treatment also was included. Blossom sampling in 2003 and 2004 was conducted immediately prior to the popcorn spray application and during bloom, with an additional sampling of leaves in 2003. Blossom samples consisted of five blossom clusters per tree and were processed as described above. Leaf samples consisted of five leaves that were processed individually. Epiphytic $P$. syringae cells were removed from leaves by sonication as previously described (10). For population enumeration, all samples were serially diluted in 10-fold steps and appropriate dilutions plated on King's B agar medium. Statistical analyses of population data were done using a one-way analysis of variance and mean separation was accomplished using Fisher's protected least significant difference test.

\section{RESULTS}

Orchard survey. From 39 orchards throughout western Michigan in 2003 and 2004, we consistently recovered $P$. syringae from blossom samples on both $\mathrm{MG}$ and MGcu media (Table 1). Within growing regions, blossom populations recovered on MG medium differed by up to 1,000-fold between orchards (Table 1). Each sample consisted of approximately 50 blossoms, indicating that orchards with sample populations ranging from 4.0 to 6.6 $\log _{10} \mathrm{CFU} / \mathrm{g}$ contained approximately 200 to $80,000 P$. syringae cells per blossom. Recovery of $P$. syringae colonies directly on MGcu was indicative of the occurrence of copper-resistant isolates in orchards. Comparison of populations from MG and MGcu enabled estimates of the frequency of copper resistance among the total epiphytic population. These frequencies differed by region over the 2-year sampling period, averaging $43.0,23.5$, and $6.6 \%$ in the southwest, west-central, and northwest regions, respectively.

Identification and phenotypic characterization of isolates. Approximately 74 and $83 \%$ of the isolates characterized in 2003 and 2004, respectively, were pathogenic (Table 2). PCR utilizing the $s y r D$ primers for $P$. syringae pv. syringae identification was conducted on the esculinhydrolyzing isolates, with 75 and $51 \%$ of the total pathogenic isolates from 2003 and 2004, respectively, identified as $P$. syringae pv. syringae (Table 2). Of the pathogenic $P$. syringae pathovars isolated, recovery of pv. morsprunorum was rare in $2003(0.5 \%)$ 
and averaged $20 \%$ in 2004. Pathogenic $P$. syringae belonging to neither pv. syringae nor pv. morsprunorum were recovered consistently from blossoms in both years and comprised approximately $25 \%$ (Table 2).

Copper resistance analysis. In all, $31.5 \%(159 / 505)$ of the pathogenic $P$. $s y$ ringae isolates were determined to be copper resistant, and $31.7 \%(100 / 315)$ of the $P$. syringae pv. syringae and $44.1 \%$ (56/127) of the $P$. syringae isolates not identified to pathovar were copper resistant. In contrast, only $1.6 \%(1 / 63)$ of the $P$. syringae pv. morsprunorum isolates was copper resistant. The subset of 56 isolates tested for copper MIC were distributed among four concentration ranges $(0.8 \mathrm{mM}$ $\mathrm{CuSO}_{4}, 1.0$ to $1.6 \mathrm{mM} \mathrm{CuSO}_{4}, 1.8$ to 2.4 $\mathrm{mM} \mathrm{CuSO}_{4}$, and 2.6 to $3.2 \mathrm{mM} \mathrm{CuSO}_{4}$ ). A total of 36 of the 56 isolates had copper MICs in the 1.0 to $1.6 \mathrm{mM}$ range along with the control copper-resistant strain, $P$. syringae pv. syringae 7B44 (40). The remaining 4, 13, and 3 isolates had copper MICs in the 0.8-, 1.8 to $2.4-$, and 2.6 to 3.2-mM range, respectively.

Ice nucleation frequency. In all, 94\% of the 315 P. syringae pv. syringae isolates characterized were positive for ice nucleation activity as determined by a qualitative freezing assay (data not shown). A quantitative analysis showed that the ice nucleation frequencies of 31 of $44 P$. syringae pv. syringae isolates were relatively high, ranging from $1.0 \times 10^{-2}$ to $8.0 \times 10^{-3}$ active ice nuclei per cell (data not shown). The ice nucleation frequencies of the other 13 isolates ranged from $1.4 \times 10^{-4}$ to $7.8 \times$ $10^{-5}$ active ice nuclei per cell (data not shown). When the ice nucleation frequencies were calculated in reverse to determine the number of cells per active ice nucleus, these numbers ranged from 11 to
15,872 cells. The mean number of cells per active ice nucleus for all 44 isolates examined was 1,884, with a standard error of 560.

DNA fingerprinting. Among the isolate collection analyzed, 27 and 31 unique bands were detected using the BOX and ERIC primers, respectively. The generated NTSYS dendrogram indicated that the $P$. syringae pv. syringae population was diverse, comprising one large group and two smaller groups (I, II, and III), with branching points at less than $38 \%$ relative genetic similarity (Fig. 1). The distribution of isolates within the groups did not correspond with geographical location of orchards from which they were recovered. The control strains $P$. syringae pv. syringae 7B44, $8 \mathrm{~B} 48$, and 7B12 isolated from ornamental pear in Oklahoma (38) and B728a isolated from bean in Wisconsin (24) clustered within group I whereas $P$. syringae pv. syringae FF5, also isolated from ornamental pear in Oklahoma, clustered within group II (Fig. 1). Copper-resistant organisms were relatively evenly distributed among the isolates in groups I and II and were absent in group III (Fig. 1). Four unknown $P$. syringae pathovars also were assayed (U1-5, U7-3, U30-4, and U43-4) and showed a clear separation from $P$. syringae pv. syringae (Fig. 1).

Copper-efficacy field trials. The background level of copper resistance among $P$. syringae isolates from the test orchard was $8.5 \%$ because 15 of 176 isolates from 22 blossom and leaf samples were resistant. In 2003, both cupric sulfate (Fig. 2A) and cupric hydroxide (Fig. 2B), applied at either two dormant applications or two dormant sprays plus one reduced rate prebloom application, reduced $P$. syringae blossom populations relative to an unsprayed control during bloom; however,

Table 2. Identification of Pseudomonas syringae isolates randomly chosen from the total isolate pool recovered from sweet cherry blossoms from 39 orchard sites in Michigan

\begin{tabular}{|c|c|c|c|c|}
\hline \multirow[b]{2}{*}{ Region } & \multirow[b]{2}{*}{ Isolates/pathogenic ${ }^{b}$} & \multicolumn{3}{|c|}{$\begin{array}{l}\text { No. of pathogenic isolates identified to } \\
\quad P \text {. syringae pathovar (\% total) }\end{array}$} \\
\hline & & pv. syringae & pv. morsprunorum & Neither pv. \\
\hline \multicolumn{5}{|c|}{$\overline{\text { Southwest }}$} \\
\hline 2003 & $42 / 32$ & $24(75.0)$ & 0 & $8(25.0)$ \\
\hline 2004 & $58 / 30$ & $17(56.7)$ & $7(23.3)$ & $6(20.0)$ \\
\hline \multicolumn{5}{|c|}{ West-central } \\
\hline 2003 & $69 / 45$ & $38(84.4)$ & 0 & $7(15.6)$ \\
\hline 2004 & $44 / 37$ & $24(64.9)$ & $3(8.1)$ & $10(27.0)$ \\
\hline \multicolumn{5}{|c|}{ Northwest } \\
\hline 2003 & $219 / 167$ & $121(72.5)$ & $2(1.2)$ & $44(26.3)$ \\
\hline 2004 & $212 / 194$ & $91(46.9)$ & $51(26.3)$ & $52(26.8)$ \\
\hline \multicolumn{5}{|c|}{ Summary } \\
\hline 2003 & $330 / 244$ & $183(75.0)$ & $2(0.8)$ & $59(24.2)$ \\
\hline 2004 & $314 / 261$ & $132(50.6)$ & $61(23.4)$ & $68(26.1)$ \\
\hline Total & $644 / 505$ & $315(62.4)$ & $63(12.5)$ & $127(25.1)$ \\
\hline
\end{tabular}

${ }^{\text {a }}$ Isolate identification as $P$. syringae pv. syringae and $P$. syringae pv. morsprunorum was done using polymerase chain reaction (PCR) with previously characterized diagnostic primers for each pathovar. Pathogenic isolates for which neither primer set produced a PCR product were assigned to neither pathovar.

${ }^{b}$ Number of isolates/number of pathogenic isolates. Fluorescent colonies on mannitol glutamate medium with a morphology typical of $P$. syringae were identified presumptively from orchard samples. Pathogenicity testing was done using isolate inoculations into immature cherry fruit. these differences were reduced 4 days later (Fig. 2A and B). At 2 weeks postbloom, $P$. syringae populations from symptomless leaves had rebounded in the control and in both copper materials applied twice dormant plus prebloom (Fig. 2A and B). In 2004, populations of $P$. syringae from popcorn-stage blossoms were larger in both copper treatments than in the control (Fig. 2C and D). Although both materials showed a reduction, relative to the control, of up to $10^{2}$ cells/g on 10 May, 5 days after application of the reduced-rate prebloom spray, these populations rebounded within 2 days under this treatment timing regime (Fig. 2C and D). We did not observe any symptoms of phytotoxicity in either year following the prebloom copper spray.

\section{DISCUSSION}

Our results indicate that populations of INA $P$. syringae pv. syringae are universally present on blossoms in sweet cherry orchards throughout Michigan and that these populations can increase the risk of infection following a predisposing frost. The role of frost injury as a predisposing factor for canker initiation in stone fruit trees by $P$. syringae pv. syringae is well known $(16,35,37,45)$. Blossom blast symptoms following frost events also are common in stone fruit and pear trees colonized by INA $P$. syringae pv. syringae $(29,46)$. Stone fruit trees contain an additional nonbacterial source of ice nuclei that can contribute to frost injury (7). However, it is the close association of the $P$. syringae $\mathrm{pv}$. syringae pathogen with frost-damaged tissue that is critical for the initiation of infection during thawing (14,37). Our results support our hypothesis that this epiphytic association and INA contributed substantially to the severe epidemic of bacterial canker on sweet cherry in Michigan that followed the 2002 freeze event during bloom.

Identification of 505 pathogenic isolates recovered from 39 sweet cherry orchards in this study indicated that $P$. syringae pv. syringae was the most prevalent pathovar, comprising $62 \%$ of the total. This observation is correlated with the knowledge that $P$. syringae pv. syringae is the predominant bacterial canker pathogen of sweet cherry (12). Genetic fingerprinting revealed that the $P$. syringae pv. syringae population was diverse and that this diversity was not dependent upon geographic source. These results are similar to those of other examinations of genetic diversity of $P$. syringae pv. syringae populations from a single host $(19,23,40)$. Recovery of $P$. syringae pv. morsprunorum was more sporadic and mostly during the 2004 season. $P$. syringae pv. morsprunorum causes bacterial canker of tart cherry, a disease in which leaf spots are the predominant symptom in Michigan, and this pathogen coexists epiphytically with $P$. syringae pv. syringae (18). It is likely that the recovery of $P$. syringae pv. 
morsprunorum from sweet cherry blossoms in this study was influenced by the adjacent locations of sweet and tart cherry orchards in Michigan. We also recovered pathogenic $P$. syringae isolates that could not be identified as either pv. syringae or pv. morsprunorum. The occurrence of these bacteria in our samples was about $25 \%$ in both 2003 and 2004. Genetic fingerprinting results indicated a clear differentiation between these $P$. syringae isolates and $P$. syringae pv. syringae (Fig. 2). In a previous examination of a variety of $P$. syringae pathovars using primer sets such as REP and BOX PCR, it was noted that strains from different pathovars possessed widely divergent fingerprints (25). Our results suggest that these $P$. syringae isolates could represent a third pathovar.
Studies are currently underway in our laboratory to identify and determine the epidemiological significance of this potential new pathovar.

The frequency of ice nucleation was relatively high for the majority of $P$. syringae pv. syringae isolates examined in this study. The frequency of ice nucleation is an important parameter because all cells of an INA bacterium are not simultaneously active ice nuclei. This trait is dependent upon the external location of the InaZ protein on cell surfaces and the linkage of InaZ with nonprotein components such as phosphatidylinositol (43). The fraction of cells of a given bacterium that can serve as an ice nucleus at a given time and temperature (ice nucleation frequency) determines the potential for that organism to cause ice nucleation and incite frost injury to plants $(21,22)$. Because ice formation propagates rapidly following nucleation, it is likely that any number greater than one active ice nucleus per blossom could result in injury and infection if the blossom is exposed to nucleating temperatures. Thus, knowledge of the ice nucleation frequencies of representative $P$. syringae pv. syringae isolates and average populations on blossoms enables an estimate of the number of active ice nuclei per blossom in Michigan sweet cherry orchards. The mean $P$. syringae population size per sweet cherry blossom in 39 orchards was 1,260 cells. The number of cells per active ice nucleus observed in 31 of $44 P$. syringae pv. syringae isolates was less than 1,260 , indicating the likelihood that sweet cherry blossoms in

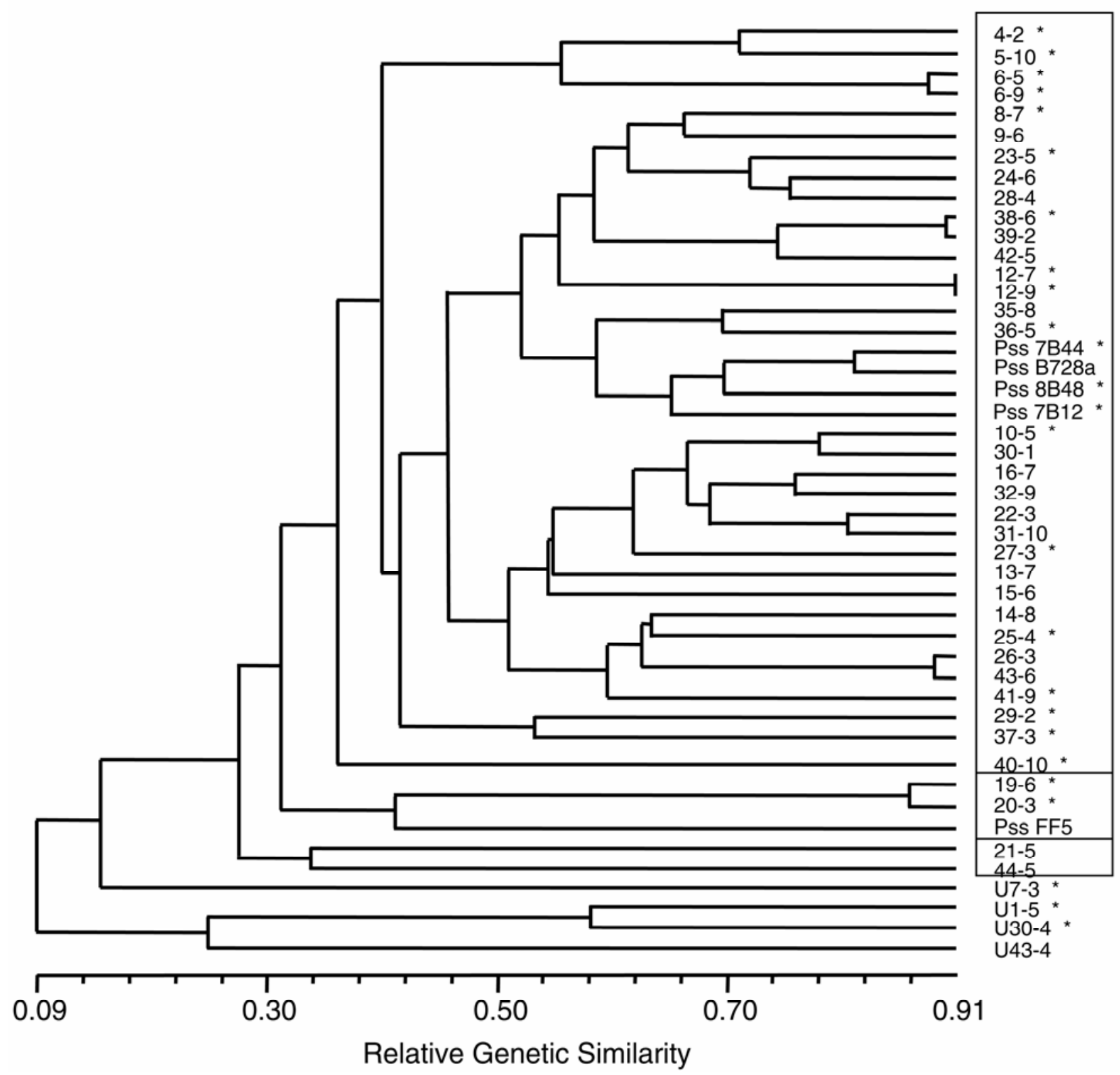

Fig. 1. Dendrogram of Pseudomonas syringae pv. syringae (numbered isolates, 4-2, 5-10, and so on) and P. syringae (U1-5, U7-3, U30-4, and U43-4) isolates derived from polymerase chain reaction fingerprints obtained by using the BOX and enterobacterial repetitive intergenic consensus (ERIC) primer sets. The dendrogram was generated from the combined BOX and ERIC data sets. Reference P. syringae pv. syringae strains (Pss B728a, Pss FF5, Pss 7B12, Pss 7B44, and Pss 8B48) also were included. Boxes denote isolate groups of $P$. syringae pv. syringae. Asterisks indicate isolates that are resistant to copper. 
Michigan orchards harbor significant numbers of active ice nuclei. The presence of these active ice nuclei provides an explanation for the wide-scale damage observed in sweet cherry orchards following the May 2002 freeze event and indicate that these orchards are at risk of subsequent infection events should another

The risk factor for shoot infection following severe frost injury signifies a need for reducing populations of $P$. syringae pv. syringae on blossoms. Our field results utilizing dormant applications of copper compounds at high rates and applications immediately prior to bloom at lower rates showed that copper was inconsistent in reducing $P$. syringae populations throughout the bloom period (Fig. 2). Because the background level of copper resistance in $P$. syringae isolates from this orchard was $8.5 \%$, it is possible that copper resistance contributed to this inconsistency. In some cases, we observed an initial reduction in cell populations followed by a rapid recovery to levels observed on unsprayed trees. freeze occur.

Sweet cherry trees are particularly susceptible to phytotoxicity from copper sprays applied after the trees break dormancy, and repeated applications are discouraged (28). Thus, although copper can be effective when used at a prebloom timing, in most cases, this reduction is short-lived.

The lack of effectiveness of copper also could be due to the development of copper resistance in isolates of the bacterial canker pathogen. Copper resistance was observed at levels greater than $10 \%$ of the total $P$. syringae blossom population in 18 of 39 orchards and was greatest in orchards located in the southwest and westcentral regions. The occurrence of copper resistance may contribute to reduced suppression of $P$. syringae epiphytic populations and loss of disease control $(4,32,39)$. However, disease control with copper can be inconsistent to none, even in the absence of copper resistance $(4,9)$. The MICs observed for copper-resistant $P$. syringae pv. syringae in this study were consistent with those observed in other $P$. syringae populations, in which plasmid-encoded
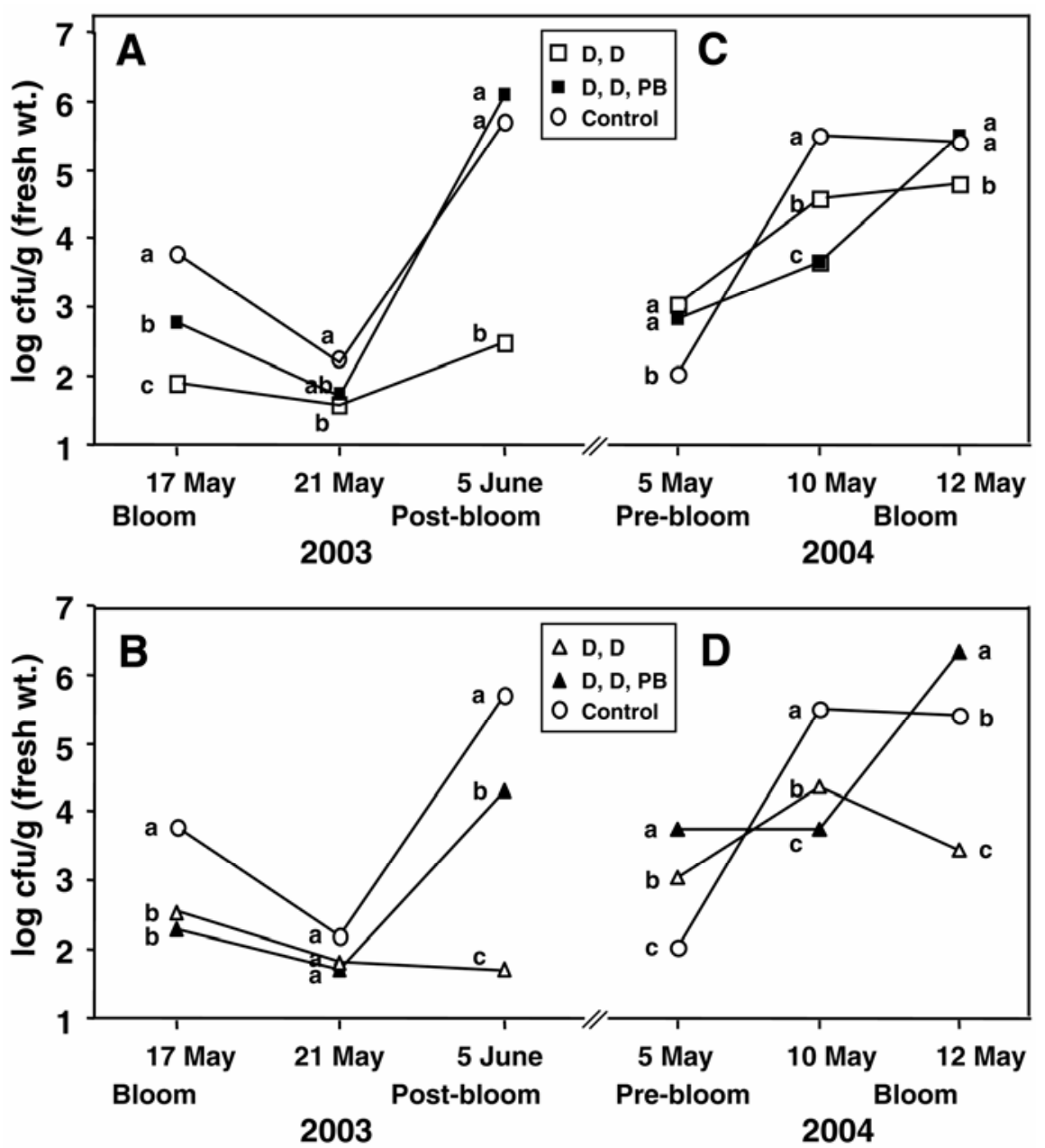

Fig. 2. Effect of applications of $\mathbf{A}$ and $\mathbf{C}$, cupric sulfate or $\mathbf{B}$ and $\mathbf{D}$, cupric hydroxide on blossom populations of Pseudomonas syringae on sweet cherry (cv. Vega). Samples collected on 17 and 21 May 2003 and 10 and 12 May 2004 were taken during bloom, 5 May 2004 prebloom (unopened flowers), and 5 June (leaves). For treatments, D indicates dormant applications and PB indicates prebloom application. Letters adjacent to population means from each sampling date signify the results of statistical analyses; means adjacent to the same letter do not differ at $P=0.05$ according to Fisher's test for least significant difference. copper resistance genes were present $(4,36)$. We have cloned a plasmid-encoded copper-resistance determinant from one of the $P$. syringae pv. syringae isolates in this study that is awaiting further characterization (A. Cogal, L. Renick, and G. Sundin, unpublished information). The presence of copper resistance genes on plasmids suggests that the determinant could be transferred among strains by conjugation or by mobilization of genes among plasmids, as has been observed in other $P$. syringae populations $(1,38,41)$. In this study, we also determined that 1 of the $63 P$. syringae pv. morsprunorum isolates and 56 of $127 P$. syringae isolates of the putative unidentified pathovar also were copper resistant. The importance of horizontal gene transfer in the development of copper resistance in these organisms is currently unknown.

There are few potential alternative bactericides for use in bacterial canker management. Antibiotics such as streptomycin and oxytetracycline have been used for many years as blossom sprays for the control of fire blight on apple and pear (26). The potential limitation of these compounds for bacterial canker control is the development of resistance; streptomycin resistance has occurred in $P$. syringae pv. syringae populations in nurseries where streptomycin was applied for disease control $(33,38)$. In addition, oxytetracycline and streptomycin resistance has developed in $P$. syringae pv. syringae populations in pear orchards in Oregon and Washington (36). The association of the streptomycin resistance genes with transferable plasmids also has exacerbated this problem $(38,40)$. Biological control is another possibility that has been used in the reduction of fire blight development on apple and pear blossoms (11), but it has not been well studied in the control of bacterial canker.

In summary, the presence of high $P$. syringae populations on blossom surfaces in Michigan sweet cherry orchards and high levels of pathogenic and INA organisms among epiphytes, accompanied by possible frost events during bloom, place orchards under a constant risk of new bacterial canker infection. In addition, the occurrence of moderately copper-resistant $P$. syringae in most orchards increases the challenges of controlling bacterial canker. We will continue to investigate novel alternatives for bacterial canker management, with an emphasis on finding tools capable of reducing $P$. syringae populations on blossoms.

\section{ACKNOWLEDGMENTS}

This work was supported by the Michigan Cherry Committee and the Michigan Agricultural Experiment Station. We thank M. Anderson, G. Ehret, and B. Klein for technical assistance in the field trials; M. Danilovic, J. Nugent, and B. Shane for assistance in locating orchards; and two anonymous reviewers whose comments significantly strengthened the manuscript. 


\section{LITERATURE CITED}

1. Bender, C. L., and Cooksey, D. A. 1986. Indigenous plasmids in Pseudomonas syringae pv. tomato: conjugative transfer and role in copper resistance. J. Bacteriol. 165:534-541.

2. Bereswill, S., Bugert, P., Volksch, B., Ullrich, M., Bender, C. L., and Geider, K. 1994. Identification and relatedness of coronatineproducing Pseudomonas syringae pathovars by PCR analysis and sequence determination of the amplification products. Appl. Environ. Microbiol. 60:2924-2930.

3. Bultreys, A., and Gheysen, I. 1999. Biological and molecular detection of toxic lipodepsipeptide-producing Pseudomonas syringae strains and PCR identification in plants. Appl. Environ. Microbiol. 65:1904-1909.

4. Cazorla, F. M., Arrebola, E., Sesma, A., PerezGarcia, A., Codina, J. C., Murillo, J., and de Vicente, A. 2002. Copper resistance in Pseudomonas syringae strains isolated from mango is encoded mainly by plasmids. Phytopathology 92:909-916.

5. Crosse, J. E. 1956. Bacterial canker of stone fruits. II. Leaf scar infection of cherry. J. Hortic. Sci. 31:212-224.

6. English, H., DeVay, J. E., Lilleland, O., and Davis, J. R. 1961. Effects of certain soil treatments on the development of bacterial canker in peach trees. (Abstr.) Phytopathology 51:65.

7. Gross, D. C., Proebsting, E. L., and Zimmerman, H. 1988. Development, distribution, and characteristics of intrinsic, nonbacterial ice nuclei in Prunus wood. Plant Physiol. 88:915-922.

8. Hattingh, M. J., Roos, I. M. M., and Mansvelt, E. L. 1989. Infection and systemic invasion of deciduous fruit trees by Pseudomonas syringae in South Africa. Plant Dis. 10:784-789.

9. Hinrichs-Berger, J. 2004. Epidemiology of Pseudomonas syringae pathovars associated with decline of plum trees in the Southwest of Germany. J. Phytopathol. 152:153-160.

10. Jacobs, J. L., Carter, T. L., and Sundin, G. W. 2005. The role of pigmentation, ultraviolet radiation tolerance, and leaf colonization strategies in the epiphytic survival of phyllosphere bacteria. Microb. Ecol. 49:104-113.

11. Johnson, K. B., and Stockwell, V. O. 1998. Management of fire blight: a case study in microbial ecology. Annu. Rev. Phytopathol. 36:227-248.

12. Jones, A. L. 1971. Bacterial canker of sweet cherry in Michigan. Plant Dis. Rep. 55:961965.

13. Keane, P. J., Kerr, A., and New, P. B. 1970. Crown gall of stone fruit. II. Identification and nomenclature of Agrobacterium isolates. Aust. J. Biol. Sci. 23:585-595.

14. Kennelly, M. M., Cazorla, F. M., de Vicente, A., Ramos, C., and Sundin, G. W. 2007. Pseudomonas syringae diseases of fruit trees: progress towards understanding and control. Plant Dis. 91:4-17.

15. King, E. O., Ward, M. R., and Raney, D. E. 1954. Two simple media for the demonstration of pyocyanin and fluorescin. J. Lab. Clin. Med. 44:301-307.

16. Klement Z., Rozsnyay, D. S., Báló, E., and Prileszky, G. 1984. The effect of cold on development of bacterial canker in apricot trees infected with Pseudomonas syringae pv. syringae. Physiol. Plant Pathol. 24:237-246.

17. Kogan, S. C., Doherty, M., and Gitschier, J.
1987. An improved method for prenatal diagnosis of genetic diseases by analysis of amplified DNA sequences. N. Engl. J. Med. 317:985-990.

18. Latorre, B. A., and Jones, A. L. 1979. Pseudomonas morsprunorum, the cause of bacterial canker of sour cherry in Michigan, and its epiphytic association with $P$. syringae. Phytopathology 69:335-339.

19. Legard, D. E., Aquadro, C. F., and Hunter, J. E. 1993. DNA sequence variation and phylogenetic relationships among strains of Pseudomonas syringae pv. syringae inferred from restriction site maps and restriction fragment length polymorphism. Appl. Environ. Microbiol. 59:4180-4188

20. Lindow, S. E. 1983. The role of bacterial ice nucleation in frost injury to plants. Annu. Rev. Phytopathol. 21:363-384.

21. Lindow, S. E., Arny, D. C., and Upper, C. D. 1978. Erwinia herbicola: a bacterial ice nucleus active in increasing frost injury to corn. Phytopathology 68:523-527.

22. Lindow, S. E., Hirano, S. S., Barchet, W. R., Arny, D. C., and Upper, C. D. 1982. Relationship between ice nucleation frequency of bacteria and frost injury. Plant Physiol. 70:10901093.

23. Little, E. L., Bostock, R. M., and Kirkpatrick, B. C. 1998. Genetic characterization of Pseudomonas syringae pv. syringae strains from stone fruits in California. Appl. Environ. Microbiol. 64:3818-3823.

24. Loper, J. E., and Lindow, S. E. 1987. Lack of evidence for in situ fluorescent pigment production by Pseudomonas syringae pv. syringae on bean leaf surfaces. Phytopathology 77:1449-1454.

25. Louws, F. J., Rademaker, J. L. W., and De Bruijn, F. J. 1999. The three Ds of PCR-based genomic analysis of phytobacteria: diversity, detection, and disease diagnosis. Annu. Rev. Phytopathol. 37:81-125.

26. McManus, P. S., Stockwell, V. O., Sundin, G. W., and Jones, A. L. 2002. Antibiotic use in plant agriculture. Annu. Rev. Phytopathol. 40:443-465.

27. Melakeberhan, H., Jones, A. L., Sobiczewski, P., and Bird, G. W. 1993. Factors associated with the decline of sweet cherry trees in Michigan-nematodes, bacterial canker, nutrition, soil $\mathrm{pH}$, and winter injury. Plant Dis. 77:266-271.

28. Mink, G. I., and Jones, A. L. 1996. Cherry diseases: their prevention and control. Pages 347-366 in: Cherries: Crop Physiology, Production and Uses. CAB International, Oxon, UK.

29. Montesinos, E., and Villardell, P. 1991. Relationships among population levels of Pseudomonas syringae, amount of ice nuclei, and incidence of blast of dormant flower buds in commercial pear orchards in Catalunya, Spain. Phytopathology 81:113-119.

30. Olson, B. D., and Jones, A. L. 1983. Reduction of Pseudomonas syringae pathovar morsprunorum on montmorency sour cherry with copper and dynamics of the copper residues. Phytopathology 73:1520-1525.

31. Sayler, R. J., and Kirkpatrick, B. C. 2003. The effect of copper sprays and fertilization on bacterial canker in French prune. Can. J. Plant Pathol. 25:406-410.
32. Scheck, H. J., and Pscheidt, J. W. 1998. Effect of copper bactericides on copper-resistant and -sensitive strains of Pseudomonas syringae pv. syringae. Plant Dis. 82:397-406.

33. Scheck, H. J., Pscheidt, J. W., and Moore, L. W. 1996. Copper and streptomycin resistance in strains of Pseudomonas syringae from $\mathrm{Pa}$ cific Northwest nurseries. Plant Dis. 80:10341039 .

34. Sneath, P. H. A. 1956. Cultural and biochemical characteristics of the genus Chromobacterium. J. Gen. Microbiol. 15:70-98.

35. Sobiczewski, P., and Jones, A. L. 1992. Effect of exposure to freezing temperatures on necrosis in sweet cherry shoots inoculated with Pseudomonas syringae pv. syringae or $P$. $s$. morsprunorum. Plant Dis. 76:447-451.

36. Spotts, R. A., and Cervantes, L. A. 1995. Copper, oxytetracycline, and streptomycin resistance of Pseudomonas syringae pv. syringae strains from pear orchards in Oregon and Washington. Plant Dis. 79:1132-1135.

37. Süle, S., and Seemüller, E. 1987. The role of ice formation in the infection of sour cherry leaves by Pseudomonas syringae pv. syringae. Phytopathology 77:173-177.

38. Sundin, G. W., and Bender, C. L. 1993. Ecological and genetic analysis of copper and streptomycin resistance in Pseudomonas syringae pv. syringae. Appl. Environ. Microbiol. 59:1018-1024.

39. Sundin, G. W., and Bender, C. L. 1994. Relative fitness in vitro and in planta of Pseudomonas syringae strains containing copper and streptomycin resistance plasmids. Can. J. Microbiol. 40:279-285.

40. Sundin, G. W., Demezas, D. H., and Bender, C. L. 1994. Genetic and plasmid diversity within natural populations of Pseudomonas syringae with various exposures to copper and streptomycin bactericides. Appl. Environ. Microbiol. 60:4421-4431.

41. Sundin, G. W., Jones, A. L., and Fulbright, D. W. 1989. Copper resistance in Pseudomona syringae pv. syringae from cherry orchards and its associated transfer in vitro and in planta with a plasmid. Phytopathology 79:861-865

42. Sundin, G. W., Jones, A. L., and Olson, B. D. 1988. Overwintering and population dynamics of Pseudomonas syringae pv. syringae and $P$. s. pv. morsprunorum on sweet and sour cherry trees. Can. J. Plant Pathol. 10:281-288.

43. Turner, M. A., Arellano, F., and Kozloff, L. M. 1991. Components of ice nucleation structures of bacteria. J. Bacteriol. 173:6515-6527.

44. Vali, G. 1971. Quantitative evaluation of experimental results on the heterogeneous freezing nucleation of supercooled liquids. J. Atmos. Sci. 28:402-409.

45. Weaver, D. J. 1978. Interaction of Pseudomonas syringae and freezing in bacterial canker on excised peach twigs. Phytopathology 68:1460-1463.

46. Whitesides, S. K., and Spotts, R. A. 1991 Induction of pear blossom blast caused by Pseudomonas syringae pv. syringae. Plant Pathol. 40:118-127.

47. Wimalajeewa, D. L. S., Cahill, R., Hepworth, G., Schneider, H. G., and Washbourne, J. W. 1991. Chemical control of bacterial canker (Pseudomonas syringae pv. syringae) of apricot and cherry in Victoria. Aust. J. Exp. Agric. 31:705-708. 